\section{エキスパートシステムの現状と課題 次世代システムへ向けて}

特 集

解 説

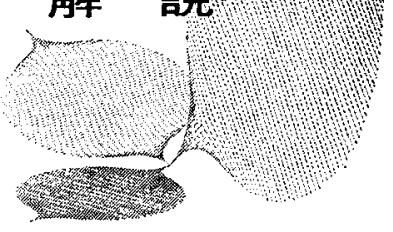

\section{1.はじめに}

人工知能の一応朋技術ししてエキスパートシステム がこと 2 3 年で急速に普及し始め，産業への適用事 例す堌加している。使用経嗝の増加に伴って, 現行エ キスパートシステムの能力とその限界が次第に正しく 認識されるようになり，エキスパートシステム技術 の内容に踏み込んだ議論も行われるようになってき た(1)。をれとともに，情報処理技術としてみたときの エキスパートシステムの位置付外，将来への見通しな ごに関心方高まっている(2)(3)。

エキスパートシステムが情報処理の新しい方向を示 すむのとして極めて重要な技術であることは間違いな い。この重要性は, 従来の計算機の適用が困難であっ た分野，特に技術系ならびに関連の諸分野に計算機を 導入する可能性を期待させるからでるる(4)。これらの 分野の応用は非定形的な作業を含み，加高度の知的 能力を要するなど，手続き的な記述を主体とする従来 の情報処理では方式的に適さないという性質をもって いる。しかし，今日のエキスパートシステムがての期 待にこたえられるだけの能力を実現しているかという と、残念ながら未だそのレベルに達してはいない。

エキスパートシステムがあつ上述の可能性はあくま で潜在的なあので, 現行エキスパートシステムは，己 の一部しか具体化していないからである。技術系の分 野にこれを適用することを前提に考えると，現行の土 キスパートシスデムは，てれまで長い科学技術の歴史 定経て育てられてきた間題解決のための科学的方法立 有效に利用する方式にはなっていない。この結果が工 キスパートシステムの能力の限界となって現われてお り，既に一部ではエキスパートシステムに対して疑問

"Current State and Problems of Expert Systems-Toward Next Generation Systems", By Setsuo Ohsuga, Member (Institute of Interdisciplinary Research, Faculty of Engineering, The University of Tokyo)
視する兆候も現われている(5)。

しかし，本来のエキスパートシステムが目指すす の，それが基盤を置いている新技術がもつ可能性は， 今日エキスパートシステムとして具体化されてきたす のよりはるかに大きなあのであって，現行システムは 多㴍な可能性の内の一つの方式を示したに過きないよ 理解すべきであらう。以下では，エキスパートシステ 么を生み出した母体である人工知能の基本に杘って, 今日のエキスパートシステムの性格と将来の発展性に つけて考察する。

なお，本稿では全体的視点から議論を進めるが，工 キスパートシステムの個々の技術および応用例につい ては本特集の他の諭文を参照されたい( ${ }^{(6)(7) 。 ~}$

\section{2. 初期の人工知能研究——探索技法}

人工知能の研究はパズルやゲームなど探索を主体と する問題を例として，一般的な探索技法を求める試み から始まったといえる ${ }^{(8)-(10)}$ 。乙れらの問題は，枠組 みとして

(a) 状態空間

(b) 個々の状態どとに与えられる可能な [手] の 集合

（c）状態と手の組み合さによって定まる次の状態 の定義加ら構成されるという共通点をむち，問題仕 “ある与えられた初期状態から目標に達するために打 つべき手を見いだすとと”という形式で表わされる。

状態は，例えば葛でいえば，盤面上の石の配置で定 まり，[手]は石を置くことである。単純なバズルの場 合を例にとると，問題解決は，(0)まず与えられた初 期状態を現在状態とし，（1)現在状態のもとで可能な 手の一つを選び，（2）それで達する次の状態を評価す る。屯しそれが許される状態ならば，新しい状態を現 在状熊として(1)亿㞔り，そうでなければ別な手を試 みる。西し現在状態には一つも可能な手がない上わか 
ったら，現在状態にくる前の状態に民る（とのよう に，木探索纪おいて，ある枝の処理がうまくいかなか ったら，パラメータなどをその枝の処理前の状態に杘 し，別の枝を試みるために当該枝への分岐点仪民ると いう制解方法を，バックトラックというう。これを繰 返して目標とする状態達する経路定見い出す。てれ は最す単純な縦形探索上呼ばれる方法であり，とのほ 加古様々な探索制御の方式が考察されている。パズ ルは一人で，ゲームは利害の相反する二人で行うとい う相違はあっても，この形の問題は状態空間が敩密に 定められていて，状態に対して秤価値を定義すること ができ，その結果によって探索（すなわち問題解決） のガイドがなされるという共通の基本メカニズムをも $\nu_{0}$

この上うな問題解決法は，岕る意味で人間のとる方 法似ているが,ゲームプログラムは人間を越えるま でには至っていない。状䈍の評価や探索のような機機 的な処理では人よりもはるが速い計算機が，ゲーム に机いては人に劣るのはなぜかを考えてみよう。

この種の問題仙状態空間が広がると探索畤間が急增 して全域探索は不可能になるため, 状態空間の大きさ により問題解法の手法が巽なってくる。人間が基を打 つ場合，ずてての可能性を考慮して手学決めている訳 ではない。人間は状態の評価をより的確に行うことも さること招がら，考慮の対象にしなければならない状

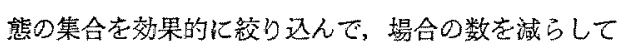
しまう。これを一般的に表現したものが，例えば基で いえば定石や格言などである。このように量が增大す ると同種の問題に対しても質的に異なった方法が要求 されるようになる。

定石や格言は非手続き的化表現された記憶情報であ る。乙れは知識である。そして，本来，探索的代評価 し，その結果によって判断するという処理を必要とし た問題を，それを経ないで斉ましてしまえることは， しの情報加々の処理に相当する効果をるつととを意昧 する。この效果は非常に大きなもので, 許容時間内の 処理が困嚾な問題です知識を用いるととにより解決さ れる例か数多くあるという意味で，知識は問题解決代 不可欠なものである。このようにして知識の重要性が 認識され，知識を部算機でも报えるようにする試みが ためされるように㣙，人工知能は知識の科学である といわれるようになった。今日, 知識工学の名のもと 代，知識を問题解決化利用するととを目的にしたシス テムが多数開発されている。

電学論 C, 107 巻 2 号, 昭 62

\section{3. 知識処理の現状}

知識を計算機で报うには，まずそれを形式化して表 現しなければならない。そのためには形式を前もって 定義しなければならない。この形式は，

（1）その形式で現わされた情報は必音処理可能で あること

（2）その形式の籍国内で必要な意味的な表現が可 能なだけの記述力をもつとと

が必要である。これらは相反する要求であり，うまい 妥協点を見い出すことが必要である。てれを定めるて とは知識表現の問題と呼ばれる。一方，知識処理には 知識を問题解沃に利用する機能が必要であり，てれは 推諭上呼ばれる機能を含む。更に知識を蓄える知識べ 一ス管理する機满が必要である。後述するように, 推猃は与えられた承つかの表琴文からて机らの表現文 と同じ意味，あるいはその意味の一部袁わす别の表 現文を導さ出す機能である。ここで表現文といったの は，上記知識表現の定める形式で表わされた文のこと である。

例えば推論の最も単純なものは,

A；‘りんどは木加ら落られば腐る’

B ; ‘りんでが (1つ) 落ちる”

という表現文の組から

C; “その) りんごは腐る”

を導出するようなもので，てれは良く知られた三段論 法である。これは単一の機能ししては単純であるが, 繰返し用いるととにより，かなり有効性を発揮する。 これらの方式はいず机も知識の表現に依存して定燨さ れ，更にて㣗を中核にして知識処理のシステムが棈成 されていく。徉って，知識表兒を定めることは知識処 理の基本問題で岕る。

今日，知識表現として多種類のものが提案されてい る。それらの基本となっているすのにプロダタション ルール, セマンティックネットワーク, 述語論理, フ レームなどがあることはよく和られている(1)。この うち最初の三つは晋吉形，最後のものは手続き形に分 類される。前三つば同じ形のものという意硛で類似で ある。前章では知識の必要性をゲーム問題から述へた が，乙れは説明の便宜のためであって，奉際にはて扎 らの知識表現がゲームから発したわりではない。ま た，この雨者の間に以下に述心゙るうに大きな相違点 がある。

ゲームの例では知識の概念を状態に基づいて導入し た。ゲームで状態が定義できたのは，状態空間の檴成 が笚純て，有限のデー夕䅉造で表就される程度のもの 
だからである。状隹空間は対象とする間題を構成して いる諸要因の組み合せとして表わされ，乙の缶味で对 象その6のを表現する㫗のであるが，それに依存する 形式の知識はこの状態架間でのみ定義されており，一 般化して譄用䈌国を広げるととが難しい。一般化する には知識表現に䇺富な記述力を与える必要があるが， それには，(i) 状態空間の丧現を強化するか，おるい

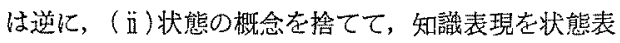
現に拘束さ机ないようにする，という二つの可能性が ある。今日のエキスパートシステムが用いている諸知 識表現はほとんどが後者に属し、形式の定められた状 態という概念は含まない。ここで状態と呼んだが，一 般的には記述される対象の正確な記述しいったほうが より広い。従っててれを捨てるととは対象このあのの 詳細な記述を捨てるてよである。

例えば，プロダクションルールでは IF-THEN の 形式を定め, THEN 部分に結諭を，IF の部分にはこ の結諭を導くための前提部として必要最小涱の条件を 㮺くことによって知識を表わす方式である。上述の 表現 A の例で示すと, 'IF りんごが木から落ちる, THEN りんでは笍る’となる。とのように IF-THEN の琲式をむつむのはルールとか規則と呼ばれる。ルー ルのみでは結論は得られず, ‘りんごが落ちた”という 事実ないしは，データにとのルールを適用するととに よって結諭が得られる。ルールが適用できるのは事実 あるいは質問がルールの前提部むしくは結諭部と一致 する場合に限られる。同じプロダクションルールとい うクラスに分類されていてあ，严語によっては变数を 含み，をてに代入される值の範国内での一致が許され るものがあり，当然記述力む上がる。前提部に䙡数の 条件を置くこと香できる。

また，入力として事实データを受り取り，その中の 一つと前提部が一致するルールを選んで適用し，その 結論部に記載されている動作を行うという方式の前進 推諭や，入力は質問であって，結諭部がてれに一致す るルールを見いだしてその前提部を新たな質問とし， 質間に一致する事実が見い出されるまでてれを続りる 後進推諭なよ゙，推諭の制御方式の買なるシステムがと の範田内で可能である。

一般に知識起理ではルールも事実古複数であって, ルールの組がルールぶースといわれる。あるいはてれ に普遍的な專実を加えて知識ベースとして与えられて いる。ことで注意すべきととは，ルールの表現につい ても，むたこのルールが適用される事实の組について も，对象学密に記述する情報あるいは状態を定義す る諸要因のなかで，当面の問題に喳接関連する一部の
情報のみが含まれ，対象や状態空間を定義する枠組み はここにはあはや存在しないことである。

このように対象や状態の表見に縛られない知識の表 現は常に外部に対して開いたものになり, 言語として は適応性が增し，広い籍囲の応用に適用できることか ら，DENDRAL，MYCIN などの初期のエキスパー トシステムが開発され，人々の関心を集めた。更に， 知識を蓄える知識ベースと，その知識老問題解決に利 用する维墖機構が分離され，沉用のッールが商用化し 始的た

実用的な問題は一般に複雜な檴成をもち，間題解决 の過程に応じて，利用される知識の種類が異なる。す ベての知識举一の知識ベースに蓄えて用いる棈成の システムではあまりに単純であり，状況に忍じててれ らを使い分けられるように，知識者前すって分割して おいた方が少なくとも效率が良い。学一の知識ベース では，知識が增すはど必要な知識老探し出すための時 間も增加するからである。このように知識を分割し， 複数の知識源を会話理解に用いるという方式をとった あのが HEARSAY II である。処理対象である音声入 力を信号レベルから音素へ，音素から文字へ，文字か ら語へ一—しいううに，順次処理していく過程で用 いられる知識は異なるため，異なる知識源に入れられ る。音声情報は埋板と呼ばれる作業場所におかれ，そ こに各知識源からの知識が作用して協調的に処理が進 められる。これは照板モデルと呼ばれる。これは知識 表現の形式というよりはシステムの形式を表わす。

黒板モデルを一般化して広い範围の問題解決ッール とすることを意図したものに AGE，ART，ESHELL などがあるが，この方式では一般に黑板上の対象に適 用する各知識源の制御問題が生ずる。また黒板上に䈯 かれるあのは処理対象のモデルであるが，会話処理の ように刘象が定まっているときは別として，一般化し たシステムとするときは，モデルを表現するための手 段，特にデータ構造を定義しなければならないが，を れがなされていない。その必然的な結果としてある 程度の一般性のある满造概念をむち，制御構造はユー ザ自身が定義できるフレームシステムへの依存もしく は共用が行われる傾问がある。

人は非常に多様な知識をもっているが，思考時にそ のすべてを使っているわけではなく，場面によって関 遇する知識の籍囲を限定している。このメカニズムは 機械による知理の場合でも効果的である。フレームは すとあと当面の思考筙国を定める枠組みしいった概念 であるが，知識処理に利用されるようになった。これ は特定の場面ごとの固有の知識をフレームという杵に 
納めているという点では黒板モデルとの共通性老す つ。更にてれらフレーム同士をメッセージの交換に上

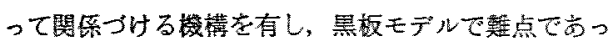

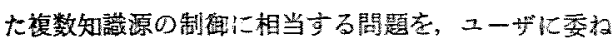

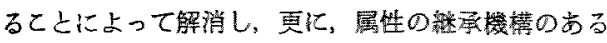

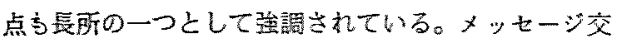

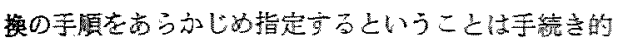

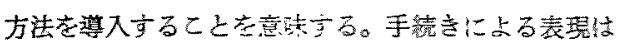

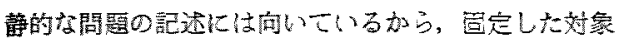

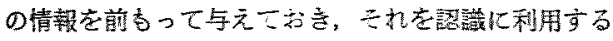

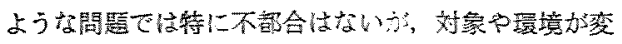

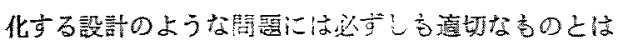

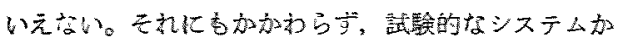

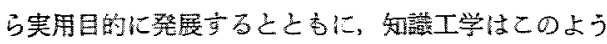

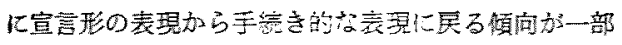
に摆われているのが現状である。

\section{4. エキスパートシステムの問題解決能力}

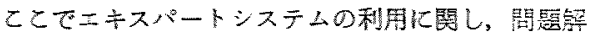

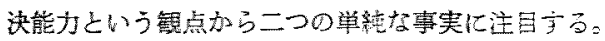

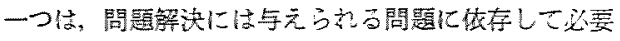

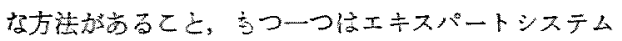

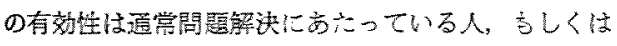

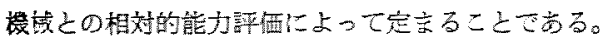

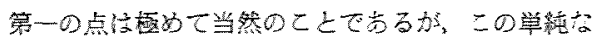

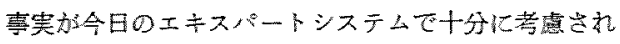

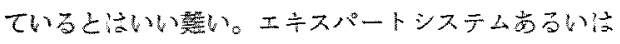

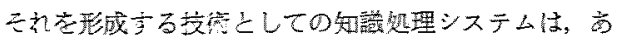

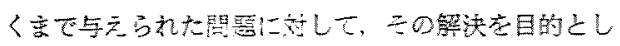

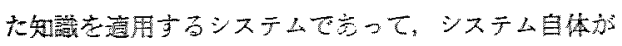

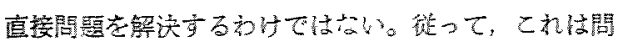

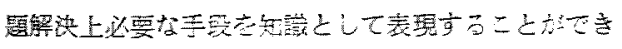

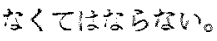

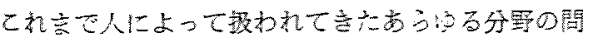

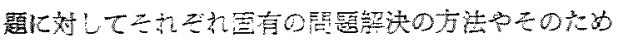

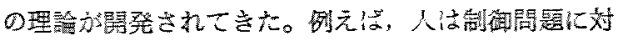

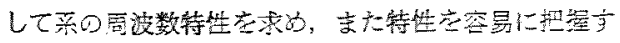

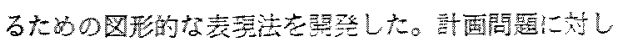

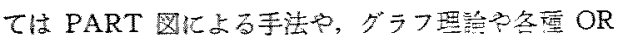

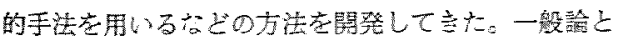

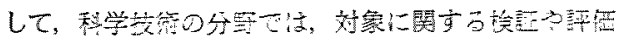

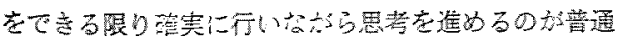

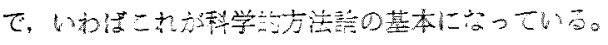

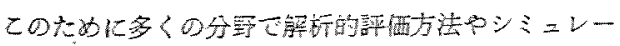

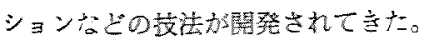

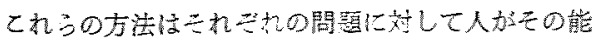

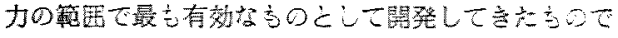

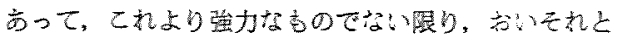

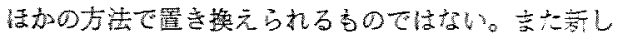

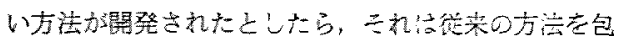

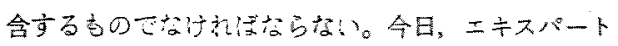

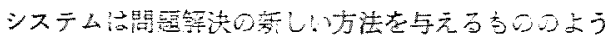

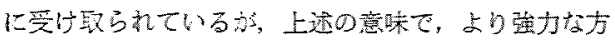

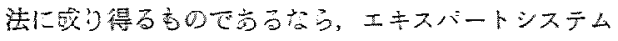

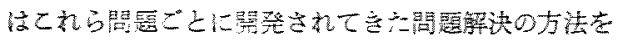

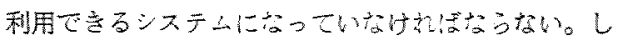

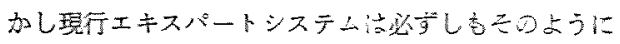
なってい心。

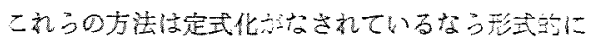

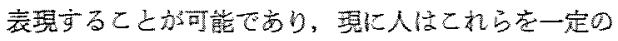

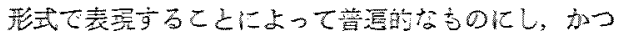
㑋いや宁くしている。今日のエキスパートシステム

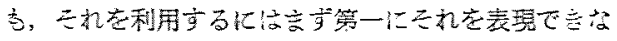

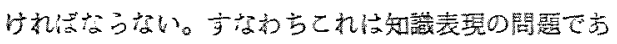

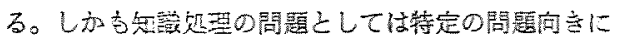

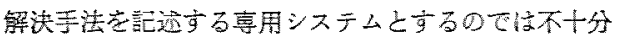

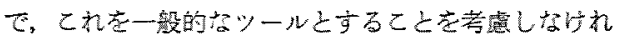

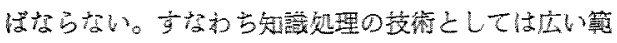

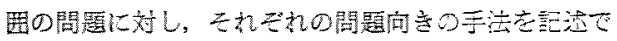

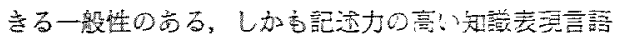

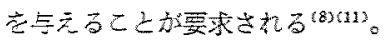

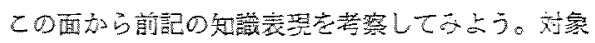

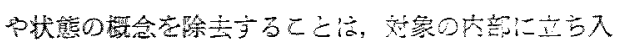

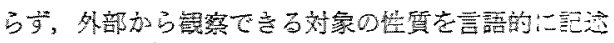

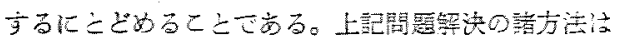

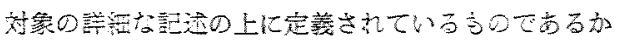

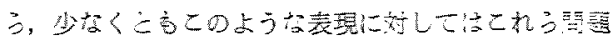

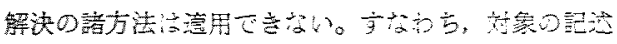

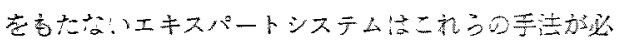

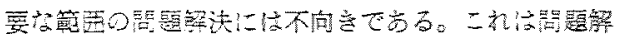

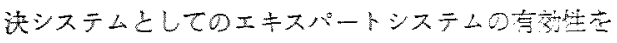
著しく削減安る。

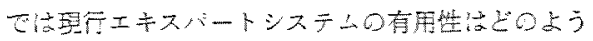

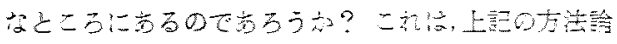

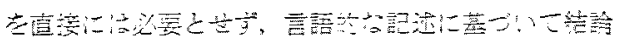

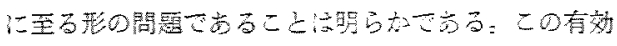

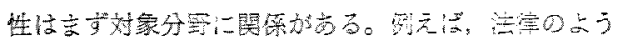

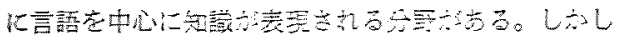

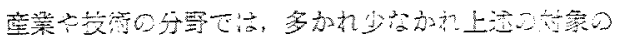

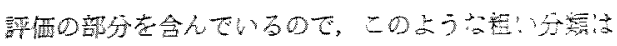

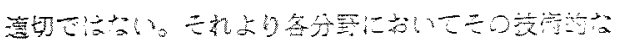

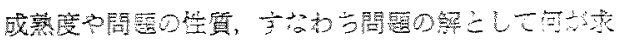


められ，何が与えられた条件であるか，などの分析を 通してての有效性を理解することが必要である。例壳 ば，新しい分野で，対象の構造などの詳細が全くわか らず，外部からの観察だけが利用可能な情報である場 合，我々は得られた知識を言語的に，あるいはたかだ かデータの形式で利用するしかない。このような分野 では経験則が重要で, 現行エキスパートシステムが役 立つ之期待される。例えば，人体の上うな複教な構造 をむった対象を技う医療の分野ではこのような段階の 情報加多い。

しかしその分野が急速に発展している場合には，乙

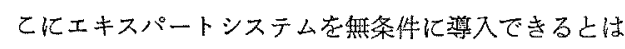
いえない。科学技術の発展とはより正しく対象を知る ことであるから，䝫日まで言語的に表現されていた知 識が今日は対象の棈造之崖質の関係の記述に变り，上

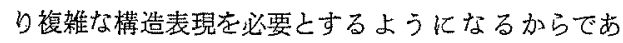
る。例えば医療の場合でも，近年の医療エレクトロニ クスの発展は人体の部分ないし全体の棈造と筷病との 関連の形の情報が多く用いら机るようになったてとを 示している。とのためのエキスパートシステムは対象 そのものを表現できるものでなくてはならない(4)(12)。

第 3 章で，知識表現の記述力を高めるには，対象構 造の表現を捨てた現行エキスパートシステムの方式と は逆に，対象構造の表現它強化する方式があると述心 たが，てれがその意味である。粠造の表現は知識表現 琣語の静的な対象の記述力の問題であるが，とのほか にェキスパートシステムにはその分野の発展に步調を 合せて成長するという動的な性質が要求される。これ が満たされないとエキスパートシステムは常に時代遅 れのものになる。それに汾野の発展に応じて常に新 しい知識を与え，あるい便新することか必要になる。 今日のエキスパートシステムではこ扎は知識獲得の問 題亡して人が行うことを前提にしているが，現実には これは面倒なあのである(14)。むしエキスパートシス テムが効象を詳細に表現するとともに，てれに前記問 題解決の諸方法を適用しなぶら対象の詳細化を合めて 知識の生成や更新をインタラクティブに計算機内で実 現できるなら，エキスパートシステムは常に最新の知 識学保有するととになる。次世代エキスパートシステ ムとしてはこのような方向に進むへきである ${ }^{(5)(15) 。 ~}$

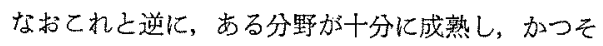
の分野に普逗的な目的がある場合に屯現行方式のエキ スパートシステムが役立つ場面がある。例穴ば化学の 分野で，ある特定の生理活性をむつ化学構造物を生成 したいという場合を想定しよう。研究を通してそのよ うな活性を古つ分子構造の權造的特街力確定的に求ま
っている場合，あるいは更に進んでそのような棈造を 6つ化学物筫の生成法を知れば十分に目的を達する場 合、それらを言語的な知識しして尧現することができ る。今日のエキスパートシステムはこのような使い方 を想定していたすのであるう。但しとの祭です，与え られた生理活性をるつ分子棈造の特徽が確定されてい るむのは化学分野全体では，むしろ少数であり，薬品 などの開発に際しては，むしろ与えられた性質をすつ 分子構造の特街を探ることが目的になっているという 現状を理解した上でエキスパートシステムを導入する 必要がある。

このようなエキスパートシステムの目的は，利用者 たる人に，既に確立されている知識を伝達することで

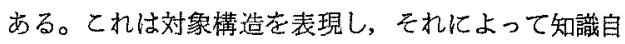
体の生成に関与するといった次世代エキスパートシス テムがもつ開発的な性質のものと異なる。知識伝達形 のエキスパートシステムがもつ效用はそれを利用する 人(あるいは機械）上の関係によって定まる。むし人 が容易に利用できるる知識しか提供できないなら，エ キスパートシステムの効用はそしい。徉って，エキス パートシステムとしては, 知識の量, 翼あるいは知識 を用いて結論を導くまでの時間なよ゙，何らかの点で人 に優れた面を借えることは絶対的な条件といってよ い。乙れは本節の冒頭にあげた二つの事実の第二のと とであることはいうまであない。伝達形エキスパート システムの効用が利用者の能力との比較によって定ま るということは，ての実用性が学㗢者の質，その他の 社会環境にも依存して評洒力゙定まることを意味する。

位達形の利用を徹底させていくと，遂には知識ベー ス上推諭機能を一体化した人工知能チップのような概 念に到達する。このようなチップの利用価值はかなり 高いととが予想される。現在の人工知能が害現してい るのは演えき推諭と呼ばれるむのであるが，てれはル ールの組の中で与えられた条件に合うものを選び出し て忠実に奏行する機構である。ルールとして一定の変 莬則を与えておけばこれは变換素子として㨐く。ルー ルは後に㫪込めばよいので，てれは沉用の变換用チッ プとして利用できよう。このような最も低いレベルの 利用から上記知識位達まで，現行エキスパートシステ ムは知的処理のうちでも低レベルの範囲, 前記知識開 発形の利用にかからない範囲、で用いれば十分に效用 を発揮するであるう。

\section{5.むすび}

人工知能の分野では記号好理をべースにした知識好 理が最近著しい発展を遂げている。本稿は人工知能の 
柽過と現状について簡単にサーベィした後，エキスパ ートシステムを産業分野に利用する際の問題点につい て述べた。今日のエキスパートシステムに结対象を詳 細に記述するという機能が次けているため，てれまで 技街分野で開発されてきた科学的方法論が十分に適用 できない。とのため利用範囷注技街の発展段階の一部 に限定される。しかしてれは知識起理の本質に関する 漾諭とは関係ない。今日のエキスパートシステムは推

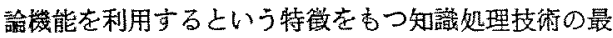

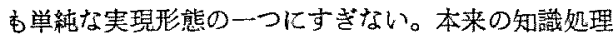

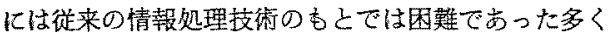
の問題汇計算機の利用を可能隹することが期待されて おり，このた如は次世代エキスパートシステムとし て，より広籁围の問題に適用できるシステムの開発䚮 急がれる。これには新しい知諳表現言語の開発が必要 である。限られた䌅面で十分意を尽くしていないが， 関連する諸問题について参考文就を御参照いただけれ ば幸いである。

(昭和 61 年 9 月 16 日受付)

\section{文献}

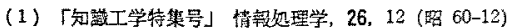

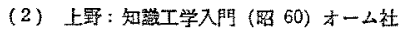

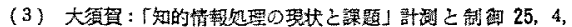
299 (明 61-4)

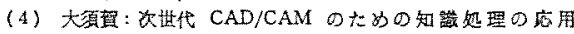
(昭 60-11) マグロウヒル・ブック

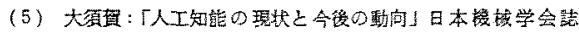
89, 815, 1112 (昭 61-10)

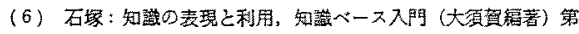
1 草 (略 61) オ一么社

(7) F. Hayes-Roth, D. Waterman, \& D. Lenet (ed.): Building Expert Systems (1983) Addison-Wesley

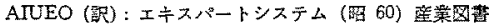

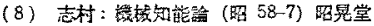

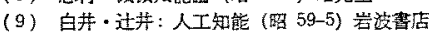

(10) E. Rich; Artifial Intelligence (1983) McGraw-Hill

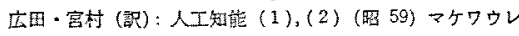
ルブック

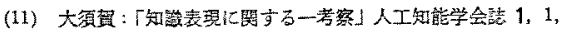
20 (昭 61-9)

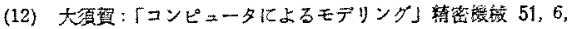
53 (昭 60-6)

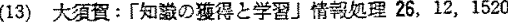
(昭 60-12)

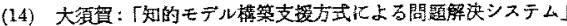

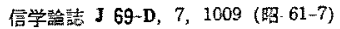

